\title{
Pengaruh Ekstrak Metanol Biji Mahoni terhadap Peningkatan Kadar Insulin, Penurunan Ekspresi TNF- $\alpha$ dan Perbaikan Jaringan Pankreas Tikus Diabetes
}

\section{Effect of Methanolic Swetenia mahagoni Seed Extracts in Increasing Insulin Level, Decreasing TNF- $\alpha$ Expression and Repairing Pancreatic Tissue Damage on Diabetic Rat}

\author{
Nany Suryani, Tinny Endang $H^{2}$, Aulanni'am ${ }^{3}$ \\ ${ }^{1}$ Sekolah Tinggi Ilmu Kesehatan Husada Borneo Banjarbaru \\ ${ }^{2}$ Laboratorium Patologi Klinik Fakultas Kedokteran Universitas Brawijaya Malang \\ ${ }^{3}$ Jurusan Biologi Fakultas MIPA Universitas Brawijaya Malang
}

\begin{abstract}
ABSTRAK
Diabetes mellitus (DM) merupakan penyakit gangguan metabolisme yang ditandai dengan meningkatnya kadar glukosa darah (hiperglikemia) akibat gangguan sekresi insulin dan atau meningkatnya resistensi insulin. Terapi ekstrak metanol biji mahoni (Swetenia mahagoni Jacq) merupakan salah satu pengobatan alternatif penyakit DM. Penelitian ini dilakukan untuk membuktikan pengaruh pemberian terapi ekstrak metanol biji mahoni terhadap kadar insulin, ekspresi TNF- $\alpha$ dan perbaikan jaringan pankreas pada tikus hasil induksi Multiple Low Dose-Streptozotocin (MLD-STZ) dosis 20 mg/kgBB selama 5 hari berturut-turut. Tikus diukur kadar glukosa darah dengan menggunakan glukometer digital dan dinyatakan DM bila kadar glukosa darahnya $\geq 300 \mathrm{mg} / \mathrm{dl}$. Penelitian ini menggunakan 25 ekor tikus putih (Rattus novergicus) jantan galur wistar yang dibagi menjadi 5 kelompok yaitu kelompok 1 kontrol negatif, kelompok 2 kontrol positif, kelompok 3, 4 dan 5 tikus hasil induksi MLD-STZ serta masing-masing diberikan terapi ekstrak metanol biji mahoni dosis $100 ; 250$ dan $400 \mathrm{mg} / \mathrm{kgBB}$ selama 7 hari. Hasil penelitian menunjukkan bahwa pemberian terapi ekstrak metanol biji mahoni dosis 100; 250 dan 400 mg/kgBB pada tikus hasil induksi MLD-STZ menunjukkan penurunan kadar glukosa darah berturut-turut sebesar 55,47\%; 81,01\% dan 73,63\%, peningkatan kadar insulin sebesar 78,38\%; 275,68\% dan 145,95\%, penurunan ekspresi TNF- $\alpha$ sebesar 30,34\%; 67,28\% dan 49,91\%, serta perbaikan kerusakan jaringan pankreas pada penurunan derajat insulitis $(p<0,05)$. Berdasarkan penelitian ini dapat disimpulkan adanya pengaruh terapi ekstrak metanol biji mahoni terhadap kadar insulin, ekspresi TNF- $\alpha$ dan kerusakan jaringan pankreas tikus hasil induksi MLD-STZ. Pengaruh terapi tersebut optimal pada pemberian biji mahoni dosis $250 \mathrm{mg} / \mathrm{kgBB}$.
\end{abstract}

Kata Kunci: Ekstrak metanol biji mahoni, ekspresi TNF- $\alpha$, insulin, kerusakan jaringan pankreas, MLD-STZ

\begin{abstract}
Diabetes Mellitus (DM) is a disease with metabolism disorder signed by increasing of glucose blood (hyperglicemia), caused by disorder of insulin secretion and or increasing of insulin resistance. Therapy of Methanolic Swetenia mahagoni Seed Extracts is an alternative treatment for DM. The objective of this research is to prove the effect of extract of Swetenia mahagoni Jacq to increasing of insulin, decreasing Tumor Necrosis Factor (TNF- $\alpha$ ) expression and repair pancreatic tissue damage of rat result Multiple Low Dose-Streptozotocin (MLD-STZ)induced dose of $20 \mathrm{mg} / \mathrm{kg}$ weight for 5 days successively. Blood glucose of rat was measured using digital glucometer and categorized as DM if it is $\geq 300 \mathrm{mg} / \mathrm{dL}$. This research used 25 wistar strained white rat (Rattus norvegicus). Which were classified into 5 groups, they are one group of negative control, one group of positive control, and three groups of MLD-STZ induced given treatment of Methanolic Swetenia mahagoni Seed Extracts with dose of 100,250 and $400 \mathrm{mg} / \mathrm{kg}$ weight for 7 days. The result showed that treatment of Methanolic Swetenia mahagoni Seed Extracts with dose of 100, 250 and $400 \mathrm{mg} / \mathrm{kgBW}$ decreased blood glucose 55,47\%; $81,01 \%$ and $73,63 \%$ successively, increased insulin as 78,38\%; $275,68 \%$ and $145,95 \%$, decreased TNF- $\alpha$ expression as $30,34 \% ; 67,28 \%$ dan $49,91 \%$, and improved damage of pancreas tissue from decreasing in the degree of insulitis ( $p<0.05)$. There was a protective effect of methanolic Swetenia mahagoni seed extract to insulin secretion, TNF- $\alpha$ expression and damage of rat pancreas tissue MLD-STZ induced. The terapeutic effect was optimal at dose of $250 \mathrm{mg} / \mathrm{kgBW}$.
\end{abstract}

Keywords: Damage of pancreas tissue, insulin, MLD-STZ, swetenia mahagoni seed extract, TNF- $\alpha$ expression

Jurnal Kedokteran Brawijaya, Vol. 27, No. 3, Februari 2013; Korespondensi: Nany Suryani. Sekolah Tinggi llmu Kesehatan Husada Borneo Banjarbaru, Jl. A. Yani Km. 30,5 No. 4 Banjarbaru Kalimantan Selatan 70712 Tel. (0511) 4784900 Email:nan_cdy@yahoo.co.id 


\section{PENDAHULUAN}

Diabetes mellitus adalah penyakit multifaktorial, yang ditandai dengan sindroma hiperglikemia kronis dan gangguan metabolisme karbohidrat, lemak serta protein yang disebabkan insufisiensi sekresi insulin ataupun aktivitas endogen insulin atau keduanya (1). Data World Health Organisation (WHO) pada tahun 2003 tercatat hampir 200 juta orang di dunia menderita diabetes dan diperkirakan pada tahun 2025 jumlah penderita bisa mencapai sekitar 330 juta jiwa (2). Secara epidemiologi, diperkirakan bahwa pada tahun 2030 prevalensi Diabetes Melitus (DM) di Indonesia mencapai 21,3 juta orang (3). Hasil Riset Kesehatan Dasar (Riskesdas) tahun 2007, diperoleh bahwa proporsi penyebab kematian akibat DM pada kelompok usia 45-54 tahun di daerah perkotaan menduduki ranking ke-2 yaitu 14,7\%. Di daerah pedesaan DM menduduki ranking ke-6 yaitu 5,8\% (4).

Diabetes Melitus (DM) tipe 1 ditandai oleh kerusakan selektif dari sel-sel beta pankreas penghasil insulin melalui mekanisme cellular mediated autoimmune. Suatu penyusupan sel-sel inflamatori ke dalam pulau langerhans, yaitu insulitis, yang diikuti oleh kematian sel beta karena proses fagositosis oleh makrofag, merupakan ciri khas kondisi patologi DM tipe 1 didominasi respon limfosit $\mathrm{T} \mathrm{CD}_{4}^{+}$penghasil IFN- $\gamma$. IFN- $\gamma$ memicu makrofag mensekresi sitokin-sitokin proinflamasi seperti IL-1 $\beta$, TNF$\alpha$ oleh sel T (5).

Mahoni merupakan salah satu tumbuhan yang digunakan masyarakat untuk pengobatan diabetes mellitus. Bagian yang digunakan dari mahoni adalah biji. Kandungan bahan kimia dari biji mahoni adalah flavonoid, alkaloid, terpenoid, antraquinon, cardiac glycosides, saponin dan volatile oils $(6,7)$. Ghosh et al melaporkan ekstrak methanol biji mahoni dosis 50 dan $100 \mathrm{mg} / \mathrm{kgBB}$ mempunyai efek farmakologi sebagai anti inflamasi, analgesik dan antipiretik pada hewan coba yang dilukai bagian telinganya (8). Selain itu pemberian ekstrak methanol: air (3:1) biji mahoni dosis $250 \mathrm{mg} / \mathrm{kgBB}$ selama 21 hari dapat menurunkan kadar glukosa darah tikus Rattus norvegicus strain wistar yang diinduksi streptozotocin (STZ) dosis tunggal $4 \mathrm{mg} / \mathrm{grBB}$ (9). Penelitian ini bertujuan untuk membuktikan pengaruh pemberian terapi ekstrak metanol biji mahoni (Swietenia mahagoni Jacq) terhadap kadar insulin, ekspresi TNF- $\alpha$ dan memperbaiki jaringan pankreas pada tikus hasil induksi Multiple Low Dose Streptozotocin (MLD-STZ)

\section{METODE}

Penelitian ini dilakukan secara ekperimental laboratorium dengan desain post test only with control group dengan menggunakan tikus putih jantan jenis Rattus norvegicus strain wistar Penelitian ini telah mendapat persetujuan komisi etik Fakultas Kedokteran Universitas Brawijaya. Penelitian dilakukan di Laboratorium Farmakologi, Laboratorium Patologi Anatomi Fakultas Kedokteran, Laboratorium Fisiologi Hewan dan Laboratorium Biokimia Fakultas Matematika dan Ilmu Pengetahuan Alam Universitas Brawijaya Malang dari bulan Juni sampai Agustus 2012.

Berdasarkan perhitungan dengan menggunakan rumus Federer ditetapkan jumlah hewan coba sebanyak 25 ekor tikus putih jantan jenis Rattus norvegicus strain wistar jantan dengan berat 100-130 gram, umur 2 bulan digunakan dalam penelitian ini. Hewan coba dibagi dalam lima kelompok masing-masing 5 ekor yaitu kelompok kontrol negatif, kelompok DM (kontrol positif), kelompok tikus DM yang diberi terapi ekstrak etanol biji mahoni dosis $100 \mathrm{mg} / \mathrm{kgBB}, 250 \mathrm{mg} / \mathrm{kgBB}$ dan $400 \mathrm{mg} / \mathrm{kg}$ BB (masingmasing 5 ekor tikus).

Pembuatan ekstrak dilakukan dengan cara maserasi menggunakan pelarut metanol (7). Serbuk biji mahoni dimasukkan ke dalam botol berwarna gelap, kemudian ditambahkan pelarut metanol, ditutup dan dibiarkan selama dua hari terlindung dari cahaya sambil diaduk, disaring sehingga didapat maserat. Ampas dimaserasi dengan metanol menggunakan prosedur yang sama, maserasi dilakukan sampai diperoleh maserat yang jernih. Semua maserat metanol digabungkan dan diuapkan dengan menggunakan evaporator pada temperature \pm $40^{\circ} \mathrm{C}$ sampai diperoleh ekstrak metanol kental. Penelitian ini menggunakan biji mahoni 159 gram biji mahoni basah kemudian dikeringkan, diperoleh 105 gram serbuk biji mahoni, selanjutnya diekstraksi dengan methanol menghasilkan ekstrak kental sebanyak 13243,2 mg.

Kadar insulin plasma diukur menggunakan metode Enzime Linked Immunosorbent Assay (ELISA). Pengukuran kadar insulin plasma dilakukan setelah pemberian ekstrak metanol biji mahoni darah diambil dari jantung. Darah yang sudah diambil dan disimpan pada suhu $-20^{\circ} \mathrm{C}$. Prosedur pengukuran dengan rat insulin ELISA kit.

Organ pankreas yang telah memadat dalam blok paraffin dipotong dengan menggunakan microtome. Pankreas diiris dengan ukuran $5 \mu \mathrm{m}$. Potongan preparat dikeringkan dan diletakkan diatas hot plate $38-40^{\circ} \mathrm{C}$ sampai kering selanjutnya preparat disimpan dalam inkubator suhu 38$40^{\circ} \mathrm{C}$ selama 24 jam.

Pengukuran ekspresi TNF- $\alpha$ dilakukan dengan menggunakan metode imunhistokimia. Pertama slide preparat dicuci dengan PBS pH 7,4 selanjutnya ditetesi dengan $3 \% \mathrm{H}_{2} \mathrm{O}_{2}$ selama 20 menit. Kemudian preparat dicuci dengan PBS pH 7,4 selama 5 menit tiga kali. Preparan diblok dengan 5\% FBS (Fetal Bovine Serum) selama 1 jam kemudian dicuci dengan PBS pH 7,4 selama 5 menit tiga kali. Preparat kemudian diinkubasi dengan antibody primer anti rat TNF- $\alpha$ selama semalam pada suhu $4^{\circ} \mathrm{C}$, kemudian dicuci dengan PBS pH 7,4 selama 5 menit tiga kali. Dilakukan inkubasi pada preparat dengan antibody sekunder anti rabbit biotin (Santa Cruz) selama 1 jam pada suhu ruang, dicuci dengan PBS $\mathrm{pH}$ 7,4 selama 5 menit tiga kali dan ditetesi dengan SA-HRP (Strep avidinHorse Radin Peroxidase) untuk diinkubasi selama 40 menit. Selanjutnya preparat dicuci dengan PBS pH 7,4 selama 5 menit tiga kali ditetesi dengan DAB (Diamino Benzidine) dan diinkubasi selama 10 menit kemudian dicuci dengan PBS pH 7,4 selama 5 menit tiga kali. Counterstaining dilakukan menggunakan Mayer Hematoxylen selama 10 menit, cuci dan keringkan. Preparat di mounting dengan entellan dan ditutup dengan cover glass. Preparat positif mengekspresikan TNF- $\alpha$ apabila terdapat warna coklat pada preparat. Selanjutnya dilakukan penghitungan persen ekspresi TNF- $\alpha$ dengan menggunakan program Axiovision.

Pewarnaan hematoxylen-eosin diawali dari tahap deparafinisasi yakni preparat dimasukkan dalam xylol bertingkat 1-3 masing-masing selama 5 menit. Selanjutnya pada tahap rehidrasi preparat dimasukkan dalam etanol bertingkat 95, 90, 80 dan 70\% masing-masing selama 5 
menit, direndam dalam aquadest selama 5 menit, preparat dimasukkan dalam pewarna hematoxylen sampai didapatkan hasil warna yang terbaik 10 menit. Preparat diuci dengan air mengalir selama 30 menit, kemudian dibilas dengan aquadest sebelum diwarnai dengan eosin. selama 5 menit. Selanjutnya dilakukan dehidrasi dengan memasukkan perparat pada seri etanol bertingkat dari 80, 90, dan 95\% hingga etanol absolut 1-3. Dilakukan clearing dengan memasukkan preparat pada xylol 1,2 dan dikeringanginkan kemudian dilakukan mounting dengan entellan.

Data yang didapat berupa data diskriptif dan disajikan dalam bentuk tabel. Analisa data dilakukan dengan menguji homogenitas, normalitas. Untuk mengetahui perbedaan antara kelompok kontrol dengan kelompok perlakuan dilakukan uji ANOVA serta untuk mengetahui hubungan dan pengaruh dari pemberian ekstrak biji mahoni dilakukan uji regresi kuadratik dengan menggunakan perangkat lunak SPSS 14.

\section{HASIL}

Kadar Glukosa Darah Tikus Hasil Induksi MLD-STZ dan Terapi Ekstrak Metanol Biji Mahoni

Pengukuran kadar glukosa darah dilakukan sebanyak 3 kali yaitu sebelum induksi MLD-STZ, setelah inkubasi 14 hari pasca induksi MLD-STZ dan setelah pemberian terapi ekstrak biji mahoni dosis 100; 250 dan 400 mg/dl terlihat pada Tabel 1, dari hasil tersebut menunjukkan terjadinya peningkatan seteal induksi dengan streptozotocin dan penuruanan kadar glukosa darah setelah mendapatkan terapi ekstrak biji mahoni. Kadar glukosa darah ini diukur dengan menggunakan glucometer digital.

Berdasarkan hasil penelitian, terlihat bahwa kadar glukosa darah kelompok tikus kontrol yaitu $(97,4 \pm 8,02)$ $\mathrm{mg} / \mathrm{dl}$ termasuk dalam rentang kadar glukosa darah tikus normal yaitu $50-135 \mathrm{mg} / \mathrm{dl}$ (10). Kadar glukosa darah pada kelompok tikus yang diinduksi MLD-STZ dosis 20 $\mathrm{mg} / \mathrm{kgBB}$ mengalami kenaikan kadar glukosa darah yaitu $(579,4 \pm 31,09) \mathrm{mg} / \mathrm{dl}$, juga termasuk dalam rentang kadar glukosa darah tikus DM yaitu $\geq 300 \mathrm{mg} / \mathrm{dl}$. Kadar glukosa darah tikus mengalami penurunan yang signifikan pasca terapi ekstrak methanol biji mahoni dosis 100; 250 dan $400 \mathrm{mg} / \mathrm{kgBB}$ yaitu $(258,0 \pm 16,32) ;(110 \pm 5,43)$ dan $(152,8 \pm 6,09) \mathrm{mg} / \mathrm{dl}$. Hasil analisa statistik menunjukkan terdapat perbedaan yang nyata $(p<0,05)$ antara kadar glukosa darah pada tikus dengan tikus yang diinduksi MLD-STZ

Tabel 1. Kadar glukosa darah tikus kontrol, DM dan terapi ekstrak metanol biji mahon

\begin{tabular}{lcc}
\hline Kelompok Perlakuan & $\begin{array}{c}\text { Rata-rata Kadar } \\
\text { Gukosa Darah }(\mathbf{m g} / \mathrm{dL})\end{array}$ & $\begin{array}{c}\boldsymbol{p} \text {-value } \\
\text { terhadap DM }\end{array}$ \\
\hline Kontrol & $97,4 \pm 8,02$ & 0,000 \\
DM & $579,4 \pm 31,09-$ & \\
Terapi $100 \mathrm{mg} / \mathrm{kgBB}$ & $258,0 \pm 16,32$ & 0,000 \\
Terapi $250 \mathrm{mg} / \mathrm{kgBB}$ & $110,0 \pm 5,43$ & 0,000 \\
Terapi $400 \mathrm{mg} / \mathrm{kgBB}$ & $152,8 \pm 6,09$ & 0,000 \\
\hline
\end{tabular}

Hubungan Dosis Esktrak Metanol Biji Mahoni dengan Kadar Glukosa Darah Tikus Hasil Induksi MLD-STZ

Berdasarkan analisis regresi kuadratik yang dilakukan dengan koefisien determinasi $R^{2}=0,978$ dan koefisien korelasi $\mathrm{R}=0,989$. Artinya model hubungan ini mampu menjelaskan keragaman kadar glukosa darah sebesar $97,8 \%$ dan mempunyai hubungan yang sangat kuat antara dosis perlakuan terhadap kadar glukosa darah. Model menghasilkan persamaan $y=462,667-2,471 x+0,004 x^{2}$ Hasil diferensiasi model regresi ordo kedua merupakan suatu persamaan linear, yaitu: $-2,471+0,008 x=0$. Penyelesaian dari persamaan kedua ini menghasilkan titik optimum $\mathrm{x}=308,875$ yang berarti dosis perlakuan ekstrak metanol biji mahoni sebesar 308,875 mg/kgBB. Penurunan kadar glukosa darah maksimum sebesar $81,052 \mathrm{mg} / \mathrm{dL}$ dicapai pada dosis perlakuan sebesar $308,875 \mathrm{mg} / \mathrm{kgBB}$.

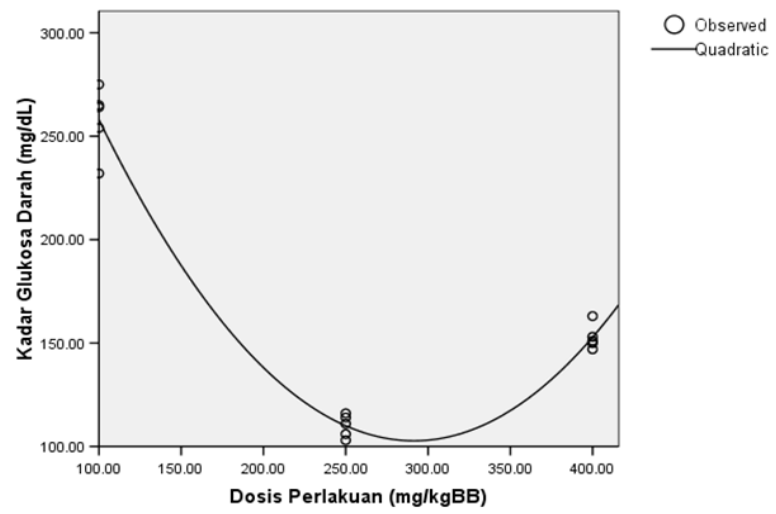

Gambar 1. Hubungan dosis ekstrak metanol biji mahoni (Swietenia mahagoni Jacq) terhadap perubahan kadar glukosa darah tikus hasil induksi MLD-STZ

Gambar 1 menunjukkan bentuk hubungan antara dosis perlakuan dengan kadar glukosa darah tikus yang diberikan ekstrak metanol biji mahoni. Hubungan tersebut menerangkan bahwa kadar glukosa darah terus menurun seiring dengan adanya pertambahan dosis ekstrak metanol biji mahoni sampai mencapai titik tertentu dan setelah melewati titik optimum akan mengalami peningkatan. Hasil perhitungan secara matematis dari model regresi kuadratik, telah diperoleh penurunan kadar glukosa maksimum sebesar $81,052 \mathrm{mg} / \mathrm{dL}$ yang dicapai pada dosis perlakuan $308,857 \mathrm{mg} / \mathrm{kgBB}$.

Kadar Insulin Tikus Kontrol, Tikus DM dan Tikus Terapi Ekstrak Metanol Biji Mahoni

Rata-rata kadar insulin plasma tikus kontrol, DM dan tikus dengan terapi ekstrak metanol biji mahoni dosis 100; 250 dan $400 \mathrm{mg} / \mathrm{kgBB}$ dapat dilihat pada Tabel 2. Pemberian ekstrak metanol biji mahoni (Swetenia mahagoni Jacq) dapat meningkatkan kadar insulin plasma. Dari Tabel 2 menunjukkan terdapat perbedaan yang nyata kadar insulin pada tikus DM dengan tikus yang mendapat terapi dosis 100; 250, $400 \mathrm{mg} / \mathrm{kgBB}(\mathrm{p}<0,05)$. Berdasarkan hasil tersebut dari ketiga dosis terapi ekstrak biji mahoni yang paling mendekati kadar insulin plasma tikus kontrol yaitu terapi dosis $250 \mathrm{mg} / \mathrm{kgBB}$. Hal ini sesuai dengan data kadar glukosa darah yang menunjukkan pemberian dosis terapi ekstrak metanol biji mahoni $250 \mathrm{mg} / \mathrm{kgBB}$ pada tikus, mempengaruhi penurunan kadar glukosa darah yang tidak berbeda dengan tikus kontrol. 
Tabel 2. Kadar insulin tikus kontrol, DM dan terapi ekstrak metanol biji mahoni (Swetenia mahagoni Jacq)

\begin{tabular}{lcc}
\hline Kelompok Perlakuan & $\begin{array}{c}\text { Rata-rata } \\
\text { Kadar Insulin }(\mathbf{n g} / \mathbf{m L})\end{array}$ & $\begin{array}{c}\boldsymbol{p} \text {-value } \\
\text { terhadap DM }\end{array}$ \\
\hline Kontrol & $3,69 \pm 0,29$ & 0,000 \\
DM & $0,74 \pm 0,22$ & - \\
Terapi $100 \mathrm{mg} / \mathrm{kgBB}$ & $1,32 \pm 0,13$ & 0,003 \\
Terapi $250 \mathrm{mg} / \mathrm{kgBB}$ & $2,78 \pm 0,34$ & 0,000 \\
Terapi 400mg/kgBB & $1,82 \pm 0,28$ & 0,000 \\
\hline
\end{tabular}

Hubungan Dosis Ekstrak Metanol Biji Mahoni dengan Kadar Insulin Tikus Hasil Induksi MLD-STZ

Berdasarkan analisis regresi kuadratik dengan koefisien determinasi $R^{2}=0,935$ dan koefisien korelasi $R=0,967$. Artinya model regresi kuadratik mampu menjelaskan keragaman kadar insulin sebesar 93,5\% dan mempunyai hubungan yang sangat kuat antara dosis perlakuan terhadap kadar insulin. Analisa regresi menghasilkan persamaan sebagai berikut: $y=-1,34+0,029 x-0,00005 x^{2}$. Hasil diferensiasi model regresi ordo kedua merupakan suatu persamaan linear, yaitu: 0,029-0,0001x=0. Penyelesaian dari persamaan tersebut menghasilkan titik optimum dosis perlakuan ekstrak metanol biji mahoni sebesar 390 mg/kgBB untuk mencapai penurunan kadar glukosa darah maksimum sebesar $2,865 \mathrm{ng} / \mathrm{dL}$.

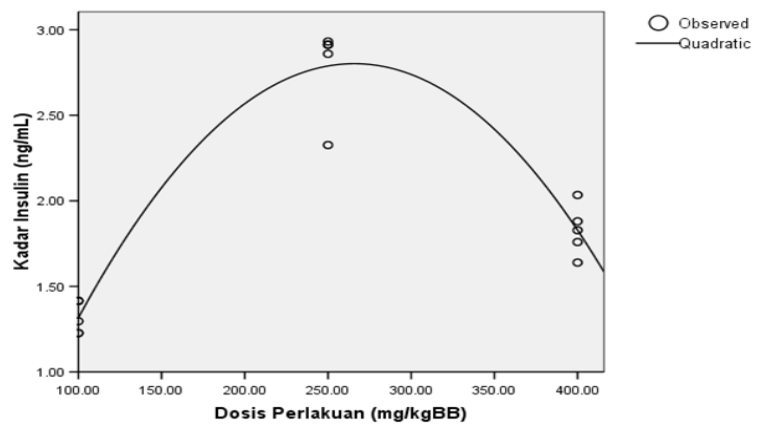

Gambar 2. Hubungan dosis ekstrak metanol biji mahoni (Swietenia mahagoni Jacq) dengan perubahan kadar Insulin pada tikus hasil induksi MLD-STZ

Gambar 2 menunjukkan bentuk hubungan antara dosis perlakuan dengan kadar insulin tikus yang diberikan ekstrak metanol biji mahoni. Hubungan tersebut menerangkan bahwa kadar insulin terus meningkat seiring dengan adanya pertambahan dosis ekstrak metanol biji mahoni sampai mencapai titik tertentu dan setelah melewati titik optimum akan mengalami penurunan. Hasil perhitungan secara matematis dari model regresi kuadratik, telah diperoleh peningkatan kadar insulin maksimum sebesar $2,865 \mathrm{ng} / \mathrm{dL}$ yang dicapai pada dosis perlakuan $290 \mathrm{mg} / \mathrm{kgBB}$.

Ekspresi TNF- $\alpha$ Jaringan Pankreas Tikus Kontrol, Tikus DM dan Tikus Hasil Terapi Ekstrak Metanol Biji Mahoni

Gambar 3 menunjukkan terjadinya penurunan ekspresi TNF- $\alpha$ karena semakin berkurangnya warna coklat pada pulau langerhans pankreas tikus pasca terapi ekstrak biji mahoni. Terapi ekstrak metanol biji mahoni dosis 250 $\mathrm{mg} / \mathrm{kgBB}$ menunjukkan penurunan ekspresi TNF- $\alpha$ yang lebih baik dibandingkan dengan dosis 100 dan 400 $\mathrm{mg} / \mathrm{kgBB}$. Hal ini sesuai dengan data kadar glukosa darah dan kadar insulin yang menunjukkan tikus terapi ekstrak metanol biji mahoni dosis $250 \mathrm{mg} / \mathrm{kgBB}$ memberikan penurunan kadar glukosa darah dan meningkatkan kadar insulin yang paling maksimum dibandingkan terapi dosis 100 dan $400 \mathrm{mg} / \mathrm{kgBB}$.
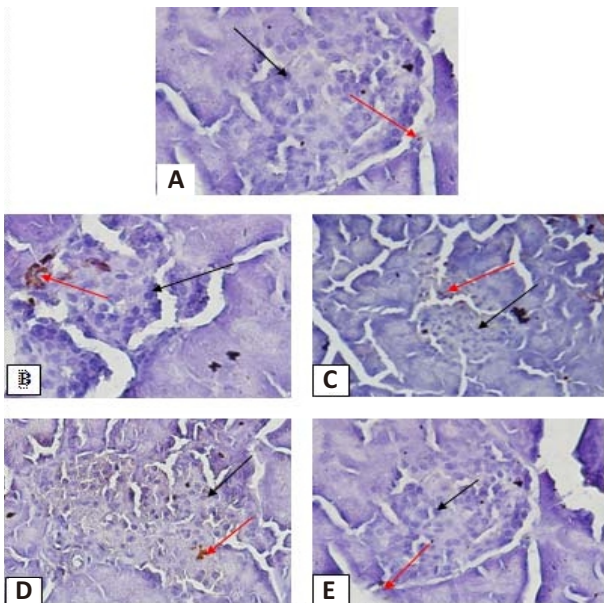

Gambar 3. Ekspresi TNF- $\alpha$ pada pulau langerhans pankreas Keterangan: A: Pulau langerhans tikus kontrol; B: Pulau langerhans tikus DM; C: Pulau langerhans tikus terapi ekstrak biji mahoni dosis 100 $\mathrm{mg} / \mathrm{kgBB}$; D: Pulau langerhans tikus terapi ekstrak biji mahoni dosis 250 $\mathrm{mg} / \mathrm{kgBB}$; E Pulau langerhans tikus terapi ekstrak biji mahoni dosis 400 mg/kgBB. Pembesaran 400x; Panah hitam: sel beta tanpa ekspresi TNF- $\alpha$; Panah merah: sel beta mengekspresikan TNF- $\alpha$.

Analisa statistik menunjukkan bahwa perlakuan terapi ekstrak biji mahoni terhadap penurunan ekspresi TNF- $\alpha$ pada tikus DM berbeda signifikan dengan tikus DM dan tidak berbeda dengan tikus kontrol. Hal ini menunjukkan bahwa secara signifikan terapi ekstrak metanol biji mahoni pada tikus DM dapat menurunkan ekspresi TNF- $\alpha$ jaringan pankreas. Perbandingan jumlah sel yang mengekspresikan TNF- $\alpha$ pada tiap perlakuan ditunjukkan pada Tabel 3.

Tabel 3. Profil jumlah sel yang mengekspresikan TNF- $\alpha$ pada tikus kontrol, tikus DM dan tikus terapi ekstrak metanol biji mahoni

\begin{tabular}{lcc}
\hline $\begin{array}{l}\text { Kelompok } \\
\text { Perlakuan }\end{array}$ & $\begin{array}{c}\text { Rata-rata Jumlah Sel } \\
\text { yang Mengekspresikan TNF- } \boldsymbol{\alpha}\end{array}$ & $\begin{array}{c}\boldsymbol{p} \text {-value } \\
\text { terhadap DM }\end{array}$ \\
\hline Kontrol & $4,16 \pm 0,75$ & 0,000 \\
DM & $17,27 \pm 1,04$ & - \\
Terapi 100mg/kgBB & $12,03 \pm 1,41$ & 0,000 \\
Terapi 250mg/kgBB & $5,65 \pm 0,57$ & 0,000 \\
Terapi 400mg/kgBB & $8,65 \pm 0,61$ & 0,000 \\
\hline
\end{tabular}

Hubungan Dosis Ekstrak Metanol Biji Mahoni dengan Ekspresi TNF- $\alpha$ Tikus Hasil Induksi MLD-STZ

Berdasarkan analisis regresi kuadratik dengan koefisien determinasi $R^{2}=0,905$ dan koefisien korelasi $R=0,951$. 
Artinya model regresi kuadratik mampu menjelaskan keragaman ekspresi TNF- $\alpha$ sebesar $90,5 \%$ dan mempunyai hubungan yang sangat kuat antara dosis perlakuan terhadap ekspresi TNF- $\alpha$. Pendugaan model tersebut dilakukan dengan bantuan program SPSS versi 14, sehingga menghasilkan persamaan sebagai berikut: $y=21,972-0,116 x+0,0002 x^{2}$. Persamaan ini dapat digunakan untuk keperluan peramalan respon ekspresi TNF- $\alpha$ berdasarkan dosis perlakuan yang diberikan dan sekaligus menentukan kondisi optimum dengan konsep deferensial. Hasil diferensiasi model regresi ordo kedua merupakan suatu persamaan linear, yaitu: $-0,116+0,0004 x=0$. Penyelesaian dari persamaan ini menghasilkan titik optimum dosis perlakuan ekstrak metanol biji mahoni sebesar $290 \mathrm{mg} / \mathrm{kgBB}$ untuk mencapai penurunan ekspresi TNF- $\alpha$ maksimum sebesar 5,152 .

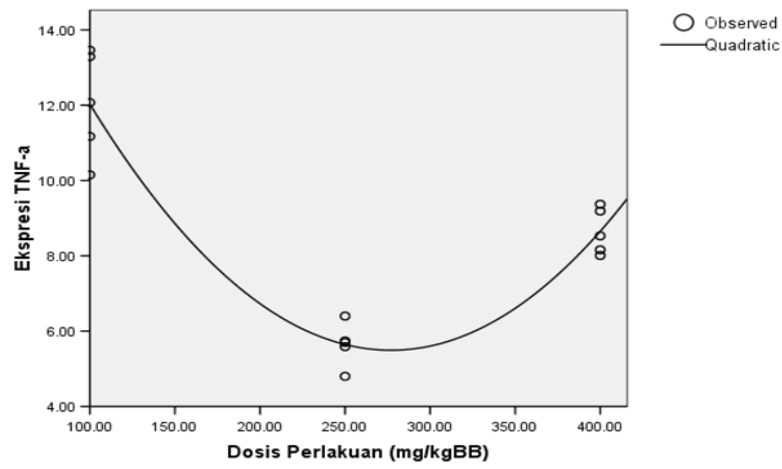

Gambar 4. Hubungan dosis ekstrak metanol biji mahoni (Swietenia mahagoni Jacq) terhadap perubahan ekspresi TNF- $\alpha$ pada tikus hasil induksi MLD-STZ

Gambar 4 menunjukkan bentuk hubungan antara dosis perlakuan dengan ekspresi TNF- $\alpha$ tikus yang diberikan ekstrak metanol biji mahoni. Hubungan tersebut menerangkan bahwa ekspresi TNF- $\alpha$ terus menurun seiring dengan adanya pertambahan dosis ekstrak metanol biji mahoni sampai mencapai titik tertentu dan setelah melewati titik optimum akan mengalami peningkatan. Hasil perhitungan secara matematis dari model regresi kuadratik, telah diperoleh penurunan ekspresi TNF- $\alpha$ maksimum sebesar 5,152 yang dicapai pada dosis perlakuan $290 \mathrm{mg} / \mathrm{kgBB}$.

Perbaikan Jaringan Pankreas (Derajat Insulitis) Tikus Kontrol, Tikus DM dan Tikus Terapi Ekstrak Metanol Biji Mahoni

Hasil penelitian (Gambar 5) menunjukkan bahwa pulau langerhans tikus kontrol masih terlihat sedikitnya rongga atau ruang interseluler dan banyak sel beta pankreas penghasil hormon insulin. Sedangkan pada tikus diabetes mellitus terdapat banyak rongga atau ruang interseluler pada pulau langerhans yang menyebabkan berkurangnya jumlah sel beta pankreas penghasil insulin. Secara kualitatif data penelitian menunjukkan adanya perbaikan jaringan pankreas yang paling baik pada pemberian terapi ekstrak metanol biji mahoni dosis $250 \mathrm{mg} / \mathrm{kgBB}$.

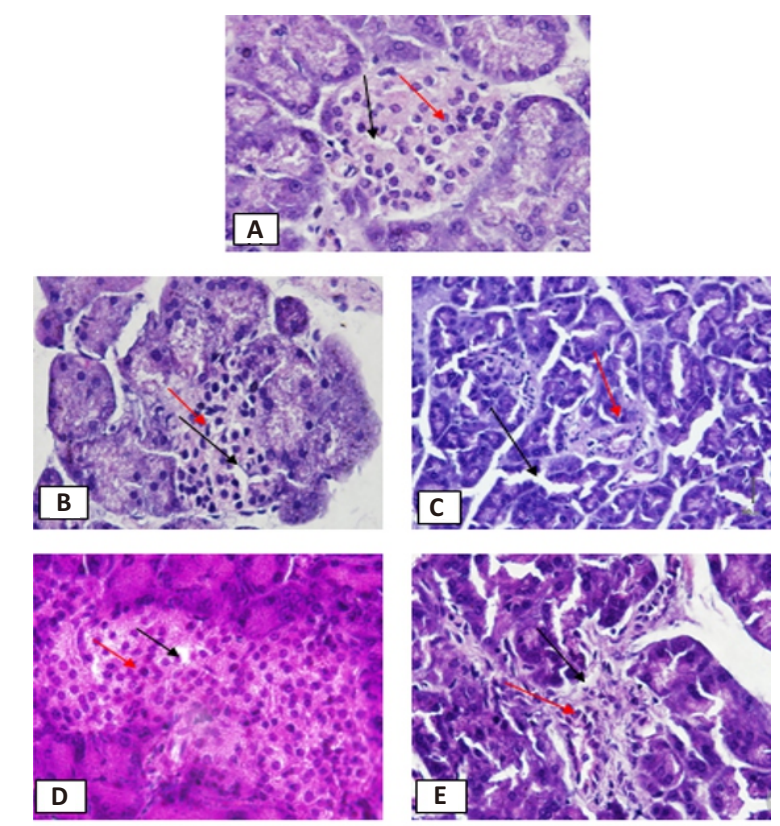

Gambar 5. Hasil pewarnaan HE pada pulau langerhans pankreas

Keterangan: A: Pulau langerhans tikus kontrol (skor 1); B: Pulau langerhans tikus DM (skor 3-4); C: Pulau langerhans tikus terapi ekstrak biji mahoni dosis $100 \mathrm{mg} / \mathrm{kgBB}$ (skor 2); D: Pulau langerhans tikus terapi ekstrak biji mahoni dosis $250 \mathrm{mg} / \mathrm{kgBB}$ (skor 1-2); E: Pulau langerhans tikus terapi ekstrak biji mahoni dosis $400 \mathrm{mg} / \mathrm{kgBB}$ (skor 1-2). Pembesaran 400x; Panah hitam: rongga interseluler; panah merah: sel beta pankreas.

Hasil analisa statistik menunjukkan bahwa rerata derajat insulitis pada terapi dosis $250 \mathrm{mg} / \mathrm{kgBB}$ berbeda secara signifikan dengan terapi dosis 100 dan $400 \mathrm{mg} / \mathrm{kgBB}$. Terapi dosis $250 \mathrm{mg} / \mathrm{kgBB}$ yang diberikan pada tikus DM menunjukkan perbaikan jaringan pankreas yang paling baik, hal ini sesuai dengan data penurunan kadar glukosa darah, peningkatan kadar insulin dan penurunan ekspresi TNF- $\alpha$ yang paling baik dibandingkan dengan pemberian terapi dosis 100 dan 400 mg/kgBB (Tabel 4).

Tabel 4. Kerusakan jaringan pankreas (derajat insulitis) pada tikus kontrol, tikus DM dan tikus terapi ekstrak metanol biji mahoni

\begin{tabular}{lcc}
\hline $\begin{array}{l}\text { Kelompok } \\
\text { Perlakuan }\end{array}$ & $\begin{array}{c}\text { Rata-rata } \\
\text { Derajat Insulitis (\%) }\end{array}$ & $\begin{array}{c}\boldsymbol{p} \text {-value } \\
\text { terhadap DM }\end{array}$ \\
\hline Kontrol & $10,00 \pm 1,58$ & 0,000 \\
DM & $77,20 \pm 6,22$ & - \\
Terapi 100mg/kgBB & $38,20 \pm 4,27$ & 0,000 \\
Terapi 250mg/kgBB & $18,40 \pm 3,58$ & 0,000 \\
Terapi 400mg/kgBB & $28,00 \pm 4,18$ & 0,000 \\
\hline
\end{tabular}

Hubungan Dosis Ekstrak Metanol Biji Mahoni dengan Perbaikan Jaringan Pankreas yang Rusak (Derajat Insulitis) Tikus Hasil Induksi MLD-STZ

Berdasarkan analisa regresi kuadratik dengan koefisien determinasi $R^{2}=0,731$ dan koefisien korelasi $R=0,855$. Artinya model regresi kuadratik mampu menjelaskan keragaman kadar glukosa darah sebesar $73,1 \%$ dan 
mempunyai hubungan yang sangat kuat antara dosis perlakuan terhadap kadar glukosa darah. Pendugaan model tersebut dilakukan dengan bantuan program SPSS versi 14, sehingga menghasilkan persamaan sebagai berikut: $y=71,155-0,352 x+0,00059 x^{2}$. Persamaan ini dapat digunakan untuk keperluan peramalan respon perbaikan jaringan pankreas yang rusak berdasarkan dosis perlakuan yang diberikan dan sekaligus menentukan kondisi optimum dengan konsep deferensial. Hasil diferensiasi model regresi ordo kedua merupakan suatu persamaan linear, yaitu: $-0,352+0,00118 x=0$. Penyelesaian dari persamaan ini menghasilkan titik optimum dosis perlakuan ekstrak metanol biji mahoni sebesar 298,31 mg/kgBB. Untuk mencapai penurunan kerusakan jaringan pankreas (derajat insulitis) maksimum sebesar 18,65.

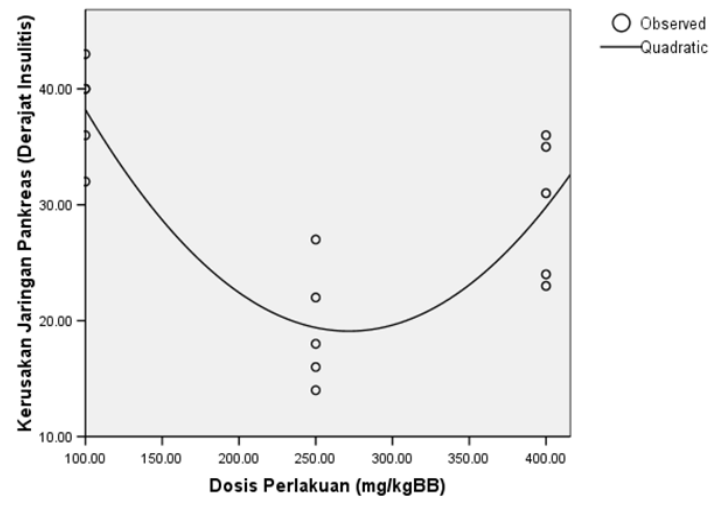

Gambar 6. Hubungan dosis ekstrak metanol biji mahoni (Swietenia mahagoni Jacq) terhadap kerusakan jaringan pankreas (derajat insulitis) tikus hasil induksi MLD-STZ

Gambar 10 menunjukkan bentuk hubungan antara dosis perlakuan dengan perbaikan jaringan pankreas tikus yang diberikan ekstrak metanol biji mahoni. Hubungan tersebut menerangkan bahwa kerusakan jaringan pankreas (derajat insulitis) terus menurun seiring dengan adanya pertambahan dosis ekstrak metanol biji mahoni sampai mencapai titik tertentu dan setelah melewati titik optimum akan mengalami peningkatan. Hasil perhitungan secara matematis dari model regresi kuadratik (persamaan 1), telah diperoleh penurunan kerusakan jaringan pankreas (derajat insulitis) maksimum sebesar 18,65 yang dicapai pada dosis perlakuan $298,31 \mathrm{mg} / \mathrm{kgBB}$.

\section{DISKUSI}

Kandungan bahan aktif dalam ekstrak biji mahoni antara lain flavonoid, alkaloid, terpenoid, antraquinon, cardiac glycosides, saponin dan volatile oils $(6,7)$. Menurut Sahgal et al. (2009) pada 1 gram ekstrak biji mahoni mengandung phenolic sebesar $26,9 \pm 0,26 \mathrm{mg}$ setara dengan asam galat dan flavonoid sebesar 2,5 $\pm 0,15 \mathrm{mg}$ setara dengan katekin (7). Bila dikonversikan dengan penelitian Sahgal et al.(2009) dari 13,243 gram ekstrak biji mahoni pada penelitian ini kandungan phenolic dan flavonoid sebesar $356,24 \pm 3,44 \mathrm{mg}$ setara dengan asam galat dan 33,11 \pm $88,29 \mathrm{mg}$ setara dengan katekin (7).
Kadar Glukosa Darah Tikus Setelah Induksi MLD-STZ dan Terapi Ekstrak Metanol Biji Mahoni

Diabetes tipe 1 ditandai dengan kerusakan sel $\beta$ pankreas melalui reaksi autoimun yang melibatkan sel $\mathrm{TCD}_{4}^{+}(\mathrm{Th})$ dan peningkatan kadar glukosa darah. Pengaruh dari induksi STZ akan meningkatkan ekspresi sel-sel inflamatori (TNF- $\alpha$, IFN- $\gamma$, IL-1 $\beta$ ) dan menimbulkan manifestasi meningkatnya kadar glukosa darah. Streptozotocin merupakan nitrosurea yang bersifat sitotoksik spesifik pada sel beta pankreas.

Induksi STZ akan menyebabkan terjadinya alkilasi DNA. Kerusakan DNA akan memicu produksi enzim poli (ADPribosa) sintase, yaitu enzim yang diperlukan untuk memperbaiki kerusakan DNA. Enzim ini memerlukan NAD (nikotinamida adenine dinukleotida) sebagai substratnya, sehingga kandungan $\mathrm{NAD}^{+}$dalam sel menurun. Menurunnya kadar $\mathrm{NAD}^{+}$selular juga menyebabkan penurunan jumlah ATP sehingga sintesis dan sekresi insulin dapat terhambat yang menyebabkan hiperglikemia. Streptozotocin sebagai donor NO yang mampu meningkatkan spesies oksigen reaktif (ROS) diantaranya radikal superoksida $\left(\mathrm{O}_{2}^{-}\right)$, radikal hidroksil $(\mathrm{OH})$ dan hydrogen peroksida $\left(\mathrm{H}_{2} \mathrm{O}_{2}\right)$. Radikal $\mathrm{NO}$ dalam bentuk bebas ataupun dalam bentuk senyawa peroksinitrit (ONOO), reaksi yang dihasilkan dari reaksi $\mathrm{NO}$ dengan $\mathrm{O}_{2}{ }^{-}$ bersifat sangat toksik terhadap sel beta pankreas karena dapat menyebabkan kerusakan DNA pankreas. Dalam mitokondria, STZ menyebabkan siklus krebs terhambat serta pemakaian oksigen dalam mitokondria pun menurun sehingga produksi ATP mitokokndria menjadi terbatas. Meningkatnya penurunan produksi ATP dalam mitokondria dapat meningkatkan pasokan substrat untuk enzim xantin oksidase akan mengkatalisis reaksi pembentukan anion superoksida $\left(\mathrm{O}_{2}{ }^{\prime}\right)$ aktif (8). Peningkatan radikal superoksida menyebabkan meningkatnya hidrogen peroksida dan radikal hidroksil yang mengakibatkan terjadinya kerusakan pankreas dan terhambatnya sentesis dan sekresi insulin sehingga terjadi hiperglikemia.

Berdasarkan hasil pengukuran menunjukkan bahwa kadar glukosa darah tikus mengalami penurunan yang signifikan pasca terapi ekstrak metanol biji mahoni dengan dosis 100; 250; dan $400 \mathrm{mg} / \mathrm{kgBB}$. Hal tersebut sesuai dengan penelitian yang telah dilakukan oleh (Linghuat dan Debasis et al) bahwa terapi ekstrak biji mahoni dapat menurunkan kadar glukosa darah tikus diabetes mellitus $(9,10)$. Penurunan kadar glukosa darah terjadi dikarenakan adanya perbaikan jaringan pankreas, sehingga dapat meningkatkan sekresi insulin akibatnya glukosa dalam darah dapat diserap kedalam sel dan dapat diubah menjadi energi atau disimpan dalam bentuk glikogen dalam hati dan otot. Hal ini juga sesuai dengan analisa korelasi antara kadar glukosa darah dengan insulin yang mempunyai hubungan (korelasi) negatif yang bermakna yaitu peningkatan kadar insulin plasma dapat menurunkan kadar glukosa darah.

Menurut Maiti et al senyawa swietenine yang diisolasi dari jenis Swietenia macrophylla memiliki efek hipoglikemik yang dapat menurunkan kadar glukosa darah (11). Ekstrak biji mahoni mengandung senyawa-senyawa yang terdiri dari flavonoid, alkaloid, terpenoid, antraquinon, cardiac glycosides, saponin dan volatile oils yang terbukti memiliki aktivitas antioksidan $(6,7)$. Aktivitas antioksidan ini mampu menangkap radikal bebas yang menyebabkan 
perbaikan pada kerusakan sel beta pankreas penyebab DM tipe 1. Dengan adanya perbaikan pada jaringan pankreas, maka terjadi peningkatan jumlah insulin didalam tubuh sehingga glukosa darah akan masuk kedalam sel sehingga terjadi penurunan glukosa darah dalam tubuh.

Pengaruh hipoglikemik ekstrak metanol biji mahoni tidak sesuai dengan dosis yang diberikan, artinya pada peningkatan dosis dari $250 \mathrm{mg} / \mathrm{kgBB}$ menjadi 400 $\mathrm{mg} / \mathrm{kgBB}$ cenderung meningkatkan kadar glukosa darah. Keadaan ini kemungkinan disebabkan karena kandungan ekstrak metanol biji mahoni yang kompleks yang masingmasing dapat bekerja secara non spesifik pada kadar glukosa darah tikus yang diinduksi MLD-STZ. Peningkatan kadar glukosa darah tikus yang diterapi dengan ekstrak metanol biji mahoni dosis $400 \mathrm{mg} / \mathrm{kgBB}$ kemungkinan juga menyebabkan kandungan antioksidan yang banyak terdapat dalam ekstrak metanol biji mahoni yang berubah menjadi prooksidan.

\section{Kadar Insulin Tikus Kontrol, Tikus DM dan Tikus Hasil Terapi Ekstrak Metanol Biji Mahoni}

Pengukuran kadar insulin tikus pada penelitian ini menunjukkan perbedaan yang bermakna antara tikus yang diberikan terapi ekstrak metanol biji mahoni dosis 100; 250 dan $400 \mathrm{mg} / \mathrm{kgBB}$ dengan tikus DM dan terjadi peningkatan kadar insulin dari tiap perlakuannya, hal ini membuktikan terapi ekstrak metanol biji mahoni selama 7 hari berturut-turut ini mampu memperbaiki kerusakan jaringan pankreas akibat induksi MLD-STZ, sehingga sel beta pankreas dapat mensekresikan insulinnya. Mekanisme kerja ekstrak metanol biji mahoni dalam meningkatkan kadar insulin belum dapat diramalkan dengan pasti. Menurut Li et al ekstrak biji mahoni mengandung kandungan agonist dengan PPARY (12). Kandungan ekstrak biji mahoni dapat bertindak sebagai ligand yang berikatan dengan PPARy. PPAR $\gamma$ adalah reseptor ligand yang terletak di dalam inti dan merupakan faktor transkripsi gen-gen yang mempengaruhi fungsi insulin. Ekstrak biji mahoni dapat memberikan efek hipoglikemik sehingga sekresi insulin dalam pulau langerhans dapat bekerja dengan baik (13).

Ekstrak biji mahoni mengandung senyawa-senyawa yang bertindak sebagai antioksidan. Antioksidan terlibat dalam proses perbaikan sel yang rusak. Kerusakan sel yang diakibatkan oleh adanya radikal bebas dapat diatasi dengan adanya antioksidan yang berfungsi sebagai agen penurun dan menurunkan oksidator sebelum merusak sel sehingga kerusakan sel dapat dikurangi (14). Salah satu senyawa yang terdapat dalam ekstrak biji mahoni yang bertindak sebagai antioksidan adalah flavonoid. Flavonoid diketahui mampu berperan menangkap radikal bebas atau berfungsi sebagai antioksidan alami (15). Aktivitas antioksidan tersebut memungkinkan flavonoid untuk menangkap atau menetralkan radikal bebas (seperti ROS atau RNS) terkait dengan gugus $\mathrm{OH}$ fenolik sehingga dapat memperbaiki keadaan jaringan yang rusak dengan kata lain proses inflamasi dapat terhambat (16). Aksi flavonoid pada diabetes mellitus adalah dapat menghindari absorbsi glukosa atau memperbaiki toleransi glukosa. Flavonoid juga dapat menstimulasi pengambilan glukosa pada jaringan perifer, mengatur aktivitas dan ekspresi enzim yang terlibat dalam jalur metabolisme karbohidrat serta dapat bertindak menyerupai insulin (insulinomimetic) dengan cara mempengaruhi mekanisme insulin signaling (13). Flavonoid dapat perperan dalam perbaikan kerusakan jaringan pankreas yang diakibatkan oleh alkilasi DNA akibat induksi STZ sebagai akibatnya dapat meningkatkan sekresi insulin dalam darah dan kadar glukosa darah dapat diturunkan.

Peningkatan dosis ekstrak metanol biji mahoni dari 250 $\mathrm{mg} / \mathrm{kgBB}$ menjadi $400 \mathrm{mg} / \mathrm{kgBB}$ memberikan efek cenderung menurunkan kadar insulin dalam darah. Keadaan ini kemungkinan disebabkan karena kandungan ekstrak metanol biji mahoni yang kompleks yang masingmasing dapat bekerja secara non spesifik pada peningkatan kadar insulin plasma tikus yang diinduksi MLD-STZ. Peningkatan kadar glukosa darah tikus yang diterapi dengan ekstrak metanol biji mahoni dosis 400 $\mathrm{mg} / \mathrm{kgBB}$ kemungkinan juga menyebabkan kandungan antioksidan yang banyak terdapat dalam ekstrak metanol biji mahoni yang berubah menjadi prooksidan. Untuk mendapatkan respon yang lebih baik, diperlukan penelitian lanjutan pada hasil fraksinasi ekstrak metanol biji mahoni ataupun senyawa yang terisolasi. Perlu juga dipelajari lebih lanjut mekanisme kerja peningkatan insulin plasma dari ekstrak metanol biji mahoni ataupun senyawa atau bahan aktif yang terisolasi dari biji mahoni.

Ekspresi TNF- $\alpha$ Jaringan Pankreas Tikus Kontrol, Tikus DM dan Tikus Hasil Terapi Ekstrak Biji Mahoni

Terapi ekstrak biji mahoni pada tikus positif diabetes mellitus menyebabkan ekspresi TNF- $\alpha$ berkurang secara bermakna. Ekspresi Tumor Necrosis Factor (TNF- $\alpha$ ) merupakan indikator utama dalam proses inflamasi akut dan terutama dihasilkan oleh fagosit mononuklear yang teraktivasi. Keberadaan TNF- $\alpha$ pada jaringan pankreas dapat menjadi indikasi kondisi patologi jaringan yang dapat digambarkan melalui metode imunohistokimia. Proses inflamasi di dalam sel akan menyebabkan teraktivasinya makrofag yang akan memproduksi sitokinsitokin proinflamasi salah satunya TNF- $\alpha$. Pada awalnya STZ sebagai agen diabetonik menyebabkan teraktivasinya limfosit $\mathrm{T}\left(\right.$ Thy-1.2+), paling sering $\mathrm{CD}^{+}$dan beberapa $\mathrm{CD} 8^{+}$ dan selanjutnya akan menyebabkan aktivasi makrofag yang akan menimbulkan inflamasi dan produksi TNF- $\alpha$. Keberadaan TNF- $\alpha$ ini menjadi penting sebagai parameter tingkat kerusakan sel beta pankreas. Mengingat peran penting TNF- $\alpha$ dapat diasumsikan bahwa ekstrak biji mahoni mampu memperbaiki jaringan prankreas yang mengalami inflamasi. Hal ini sesuai dengan penelitian Gosh et al, bahwa pemberian ekstrak metanol biji mahoni dosis 50 dan $100 \mathrm{mg} / \mathrm{kgBB}$ selama 7 hari mempunyai efek farmakologi sebagai antiinflamasi (17).

Ekstrak biji mahoni mengandung senyawa yang memiliki aktivitas antioksidan sebagai penangkap radikal bebas. Penangkapan radikal bebas oleh senyawa yang terkandung pada biji mahoni menyebabkan berkurangnya kerusakan pada jaringan pankreas, sehingga infiltrasi sel mononuklear ke dalam jaringan pankreas pada proses fagositosis sel beta yang rusak juga berkurang. Keadaan ini menyebabkan menurunnya proses inflamasi sehingga produksi TNF- $\alpha$ pun menurun dan terjadi perbaikan sel beta pankreas penghasil insulin. Hal ini sesuai dengan analisa korelasi yang memiliki hubungan (korelasi) positif yang bermakna antara penurunan ekspresi TNF- $\alpha$ dengan penurunan derajat insulitis pada perbaikan jaringan pankreas. Penurunan nilai ekspresi TNF- $\alpha$ dapat mempengaruhi penurunan derajat insulitis sehingga dapat terjadi perbaikan kerusakan jaringan pankreas. 
Perbaikan Jaringan Pankreas (Derajat Insulitis) Tikus Kontrol, Tikus DM dan Tikus DM yang Mendapat Terapi Ekstrak Biji Mahoni

Induksi agen diabetonik STZ menyebabkan peradangan sel beta pankreas (insulitis). Insulitis merupakan suatu penyusupan atau infiltrasi sel-sel mononuclear ke dalam pulau langerhans dari jaringan pankreas. Pada insulitis sel yang mendominasi adalah sel mononuclear (makrofag, limfosit dan monosit) (14). Tingkatan infiltrasi sel-sel mononuclear ke dalam pulau langerhans pada jaringan pankreas dapat diketahui dengan menghitung derajat insulitis. Skor derajat insulitis berkisar antara 0-4. Skor 0, tidak ditemukan lesi; skor 1 , terdapat insulitis $<25 \%$; skor $2,<50 \%$ pulau langerhans diinfiltrasi; skor $3,<75 \%$ pulau langerhans diinfiltrasi; skor $4,>75 \%$ mengalami infiltrasi atau degenerasi.

Berdasarkan analisa statistik menunjukkan perbaikan jaringan pankreas tikus terapi berbeda dengan tikus DM. Hal ini menunjukkan bahwa terapi ekstrak metanol biji mahoni pada tikus DM dapat menurunkan skor derajat insulitis jaringan pankreas. Pemberian terapi ekstrak biji mahoni dosis 100; 250; 400 mg/kgBB menunjukkan penurunan skor derajat insulitis yang berakibat pada perbaikan kerusakan jaringan pankreas. Ekstrak biji mahoni mengandung senyawa-senyawa dan bahan aktif yang memiliki aktivitas antioksidan. Selain itu ekstrak biji mahoni mempunyai efek farmakologi sebagai antiinflamasi (17). Aktivitas antioksidan pada ekstrak biji mahoni mampu menangkap radikal bebas, sehingga dapat terjadi perbaikan pada kerusakan jaringan pankreas. Dengan demikian proses terjadinya radang akan berkurang dan aktivitas makrofag pun juga terhambat sehingga terjadi penurunan fagositosis sel beta pankreas.

Pengaruh Ketiga Dosis Ekstrak Metanol Biji Mahoni terhadap Kadar Glukosa Darah, Kadar Insulin, Ekspresi TNF- $\alpha$ dan Derajat Insulitis

Ekstrak metanol biji mahoni secara bermakna $(p<0,05)$ dapat menurunkan kadar glukosa darah, meningkatkan kadar insulin plasma, menurunkan ekspresi TNF- $\alpha$ dan menurunkan derajat insulitis pada kerusakan jaringan pankreas tikus yang diinduksi MLD-STZ. Terlihat pada Tabel 5 dari ketiga dosis terapi ekstrak metanol biji mahoni, dosis $250 \mathrm{mg} / \mathrm{kgBB}$ merupakan dosis yang menunjukkan hasil yang paling mendekati tikus kontrol baik itu dilihat dari penurunan kadar glukosa darah, pengingkatan kadar insulin, penurunan ekspresi TNF- $\alpha$ maupun penurunan derajat insulitis pada perbaikan jaringan pankreas.

Pada dosis $400 \mathrm{mg} / \mathrm{kgBB}$ efeknya justru lebih kecil dibandingkan dengan dosis $250 \mathrm{mg} / \mathrm{kgBB}$. Hal tersebut kemungkinan terkait dengan banyaknya kandungan senyawa dan bahan aktif yang ada pada ekstrak biji mahoni yang kompleks yang masing-masing dapat bekerja secara tidak spesifik pada tikus hasil induksi MLD-STZ. Hal ini sering dijumpai pada aktivitas ekstrak bahan alam yang merupakan campuran multikomponen. Dimana komponen-komponen tersebut dapat saling sinergis, aditif maupun antagonis. Kemungkinan pada dosis yang lebih besar ekstrak metanol biji mahoni dapat memperparah atau tidak berpengaruh pada perbaikan kerusakan jaringan pankreas juga tidak dapat diabaikan. Kemungkinan penjelasan lain diduga peningkatan dosis ekstrak metanol biji mahoni dari 250 menjadi 400 $\mathrm{mg} / \mathrm{kgBB}$ menyebabkan kandungan senyawa-senyawa dalam biji mahoni yang bertindak sebagai antioksidan mengalami perubahan menjadi prooksidan. Keadaan ini juga sesuai dengan pendapat Gordon yang menyatakan bahwa besar konsentrasi antioksidan yang ditambahkan dapat berpengaruh pada laju oksidasi (18). Pada konsentrasi tinggi, aktivitas antioksidan grup fenolik sering lenyap bahkan antioksidan tersebut berubah menjadi prooksidan. Oleh karena itu peningkatan dosis ekstrak biji mahoni sebagai antioksidan dapat mengubah fungsi antioksidan sehingga beralih fungsi menjadi prooksidan yang dapat merusak sel sebagaimana radikal bebas. Untuk itu perlu dikaji lebih lanjut efek toksik dari ekstrak metanol biji mahoni dalam kaitannya dengan penggunaannya sebagai terapi protektif pada perbaikan kerusakan jaringan pankreas.

Berdasarkan hasil analisa regresi kuadratik, terlihat adanya penurunan kadar glukosa darah sampai titik maksimum yaitu pada pemberian dosis maksimum $308,857 \mathrm{mg} / \mathrm{kgBB}$ dengan kadar glukosa darah sebesar $81,052 \mathrm{mg} / \mathrm{dL}$. Pada pemberian dosis melebihi $308,857 \mathrm{mg} / \mathrm{kgBB}$ kadar glukosa darah mengalami peningkatan kembali. Terjadi peningkatan kadar insulin sampai pada titik maksimum yaitu pada dosis $290 \mathrm{mg} / \mathrm{kgBB}$ dengan kadar insulin sebesar 2,865 ng/dL. Pada pemberian dosis melebihi 290 $\mathrm{mg} / \mathrm{kgBB}$ kadar insulin mengalami penurunan kembali. Terjadi penurunan ekspresi TNF- $\alpha$ sampai pada titik maksimum yaitu pada dosis $290 \mathrm{mg} / \mathrm{kgBB}$ dengan nilai ekspresi TNF- $\alpha$ sebesar 5,152. Pada pemberian dosis melebihi 290 mg/kgBB ekspresi TNF- $\alpha$ mengalami peningkatan kembali. Terjadi penurunan kerusakan jaringan pankreas sampai pada titik maksimum yaitu pada dosis 298,31 mg/kgBB dengan nilai derajat insulitis sebesar 18,65. Pemberian dosis melebihi dosis 298,31 $\mathrm{mg} / \mathrm{kgBB}$ kerusakan jaringan pankreas (derajat insulitis) mengalami peningkatan kembali. Hasil analisa tersebut dapat memberikan informasi rata-rata dosis maksimum yang diberikan pada tikus hasil induksi MLD-STZ. Rata-rata dosis ekstrak biji mahoni maksimum sebesar 296,792 $\mathrm{mg} / \mathrm{kgBB}$ yang memberikan pengaruh yang maksimum pula pada penurunan kadar glukosa darah, kadar insulin, ekspresi TNF- $\alpha$ dan dalam memperbaiki kerusakan jaringan pankreas. Penggunaan dosis yang melebihi dosis $296,792 \mathrm{mg} / \mathrm{kgBB}$ akan memberikan dampak negatif, sehingga dalam pengunaannya harus dengan kehatihatian.

Dapat disimpulkan bahwa pemberian terapi ekstrak methanol biji mahoni dosis 100; 250 dan 400 mg/kgBB pada tikus yang diinduksi MLD-STZ menunjukkan adanya perbaikan gambaran histologis jaringan pankreas. Dosis yang memberikan efek mendekati kontrol adalah dosis $250 \mathrm{mg} / \mathrm{kgBB}$ yang menunjukkan efek optimal dari peningkatan kadar insulin sebesar $275,68 \%$, penurunan ekspresi TNF- $\alpha$ sebesar $67,29 \% \%$ dan perbaikan jaringan pankreas yang rusak sebesar $76,17 \%$. 


\section{DAFTAR PUSTAKA}

1. Sivakumar S and Subramanian SP. Pancreatic Tissue Protective Nature of D-Pinitol Studied in Streptozotocin-Mediated Oxidative in Experimental Diabetic Rats. European Journal of Pharmacology. 2009; 22: 56-70.

2. World Health Organization. Diabetes. (Online) 2006. http://www.who.int/mediacentre/factsheets/ fs312/en/

3. American Diabetes Association. Standards of Medical Care in Diabetes-2011. Diabetes Care. 2011; 34: S11S61

4. Departemen Kesehatan RI. Jumlah Penderita Diabetes Indonesia Ranking ke-4 Di Dunia. (Online) 2011. http://www.depkes.go.id/index.php?option $=$ news \&task=viewarticle\&sid $=1183 \& \mid$ temid $=2$ [direkam pada 12 Maret 2011].

5. Karen GB dan Iris R. Imunologi Dasar. Jakarta: Fakultas Kedokteran Universitas Indonesia; 2010.

6. Hajli Z. Isolasi Senyawa Golongan Flavonoid Biji Mahoni (Swetenia mahagoni Jacq) yang Berpotensi sebagai Antioksidan. [Repository]. Institut Pertanian Bogor, Bogor. 2011.

7. Sahgal G, Ramanathan S, Sasidharan S, Mordi MN, Ismail S, and Mansor SM. Phytochemical and Antimicrobial Activity of Swetenia Mahagoni Crude Methanolic Seed Extract. Tropical Biology. 2009; 26: 274-279.

8. Nugroho BA dan Puwaningsih E. Pengaruh Diet Ekstrak Rumput Laut (Eucheuma sp.) terhadap Kadar Glukosa Darah Tikus Putih (Rattus norvegicus) Hiperglikemik. Media Medika Indonesia. 2004; 39(3): 154-160.

9. Linghuat R. Uji Efek Ekstrak Etanol Biji Mahoni (Swietenia mahagoni Jaca) terhadap Penurunan Kadar Gula Darah Tikus Putih. Universitas Sumatra Utara, Medan. 2008.

10. De D, Chatterjee K, Ali KM, Bera TK, and Ghosh Debidas. Antidiabetic Potentiality of the Aqueous-
Methanolic Extract of Seed of Swieteniamahagoni (L.) Jacq. In Streptozotocin-Induced DiabeticMale Albino Rat: A Correlative and Evidence-Based Approach with Antioxidative and Antihyperlipidemic Activities. Evidence-Based Complementary and Alternative Medicine. 2010; 2011 (2011): 11.

11. Maiti AS, Dewanjee, and Sahu R. Isolation of Hypoglycemic Phytoconstituent from Swietenia Macrophylla Seeds. Phytotherapy Research. 2009; 23(12): 1731-1733.

12. Li DD, Chen JH, Chen Q, et al. Swetenia Mahagony Extract Shows Agonistic Avtivity to PPARY and Gives Ameliorative Effects on Diabetic $d b / d b$ mice. Acta Pharmacol Sinica. 2005; 26(2): 220-222.

13. Geethaa, Sahgal, Ramanathan S, et al. Brine Shrimp Lethality and Acute Oral Toxicity Studies on Swetenia Mahagoni (Linn) Jacq. Seed Methanolic Extract. Pharmacognosy Research. 2010; 2(4): 215-220.

14. Robinovitch A, Pinzon WS, Sorensen L, Bleackley R, and Power RF. IFNY Gene Expression in Pancreatic Islet Infiltrating Mononuklear Cells Correlates With Autoimmune Diabetes in Non Obese Diabetic Mice. Journal Immunology. 1995; 154: 4874-4882.

15. Lugasi A, Hovari J, Sagi KV, and Biro L. The Role of Antioxidant Phytonutients in the Prevention of Diseases. Acta Biologica Szegediensis. 2003; 47: 119125.

16. Botutihe. Efek Ekstrak Rumput Laut Coklat (Sargasum duplicatum Bory) terhadap Profil Radikal Bebas dan Protein Kinase C Paru Tikus (Rattus novegicus) yang dipapar Benzo[A]piren. [Tesis]. Universitas Brawijaya, Malang. 2010.

17. Ghosh S, Besra SE, Roy K, Gupta JK, and Vedasiromoni JR. Pharmacological Effects of Methanolic Extract of Swetenia Mahagoni Jaca (meliaceae) Seeds. International Journal of Green Pharmacy. 2009; 3: 206-210.

18. Pokorny J, Yanishlieva N, and Gordon M. Antioxidants in Food - Practical Applications. New York: Woodhead Publishing, CRC Press; 2001; p. 285-310. 